\title{
Designing Online Learning Environment: ICT Tools and Teaching Strategies
}

\author{
By Nataliya Samoylenko ${ }^{*}$ Ludmila Zharko ${ }^{ \pm}$\& Aleksandra Glotova ${ }^{\ddagger}$
}

\begin{abstract}
The authors analyze the capabilities of Information and Communication Technologies (ICT) and e-learning tools applied in the educational process through all levels of Higher Education in Russia: Bachelor's/Master's Degree Programmes and Professional Training. The article is based on the data obtained during the study organized at Sevastopol State University, Lomonosov Moscow State University Branch in Sevastopol, V.I. Vernadsky Crimean Federal University, Institute of Foreign Languages (Simferopol) and S.I. Georgievsky Medical Academy in 2019. The participants of the research were undergraduate students, educators and applicants of further Professional Training programmes. The research aimed at the analysis of ICT and e-learning tools used to design online learning environment at university. The study included a survey to identify e-learning tools applied by students and professors in educational process. The authors also specify blended learning peculiarities in Higher Education. The results showed that ICT and e-learning tools are widely used at universities to manage educational process, establish various forms of communication and interaction, to conduct an assessment and evaluate progress, to organize team projects in blended learning. ICT and online educational services are also applied to develop students' language and professional skills.
\end{abstract}

Keywords: online learning, e-learning tools, blended learning, teaching strategies, autonomy.

\section{Introduction}

Higher Education is aimed at preparing highly skilled professionals needed in various spheres for economic growth and prosperity. It has been also associated with conducting research and designing innovations. Over the past 20 years, Higher Education in Russia and other countries has changed greatly. The factors affecting this transformation include various political, social, and cultural processes (e.g., globalization, states' partnership and collaboration, cross-cultural communication, increased migration, business, and academic mobility, etc.).

Besides, the $21^{\text {st }}$ century is considered to be the period of great technological advance or digital age. World Wide Web and numerous evolving digital technologies have formed a new paradigm of Higher Education and Professional Training in Russia and other parts of the world.

First of all, the technologies and digitalization have influenced the way young students perceive and process information, their interaction patterns in the educational process, and day-to-day communication. Young people are also called now "Generation Z", "Digital Natives", "Internet Generation", "Home Landers",

\footnotetext{
*Associate Professor, Sevastopol State University, Russia.

${ }^{ \pm}$Lecturer, V.I. Vernadsky Crimean Federal University, Russia.

${ }^{\ddagger}$ Senior Lecturer, Lomonosov Moscow State University, Branch in Sevastopol, Russia.
} 
etc. (Nikonov \& Shamis, 2016; Picciano, 2009; Picciano, 2017). We cannot ignore the importance of technologies in their life.

Secondly, the modern educational system is focused on lifelong learning priority. Online learning facilities offer various opportunities to get new knowledge and develop students' skills through engagement and interaction in new learning environments. The implementation of the "open education" concept has changed the way learners may acquire, share, and consolidate knowledge, having practically unlimited access to high-quality education and learning materials. Thus, the simple transfer of knowledge is not so relevant in digital environment as the development of students' creative potential, professional skills and competencies with the potential of technologies and face-to-face communication. So, facilitative interaction is regarded as the primary trend in Higher Education.

These factors explain the popularity of e-learning associated with the widespread use of Information and Communication Technologies (ICT) and other technologies for distance education.

As a result, various e-learning tools, blended learning models and techniques are being incorporated officially into the system of educational institutions of Russia at various levels, including Higher Education and additional Professional Training (Garant Company Legal Information System, 2008). Regarding Russian educational reforms, modern e-learning is one of the means to increase the motivation of students, quality of education, and the effectiveness of Professional Training.

The use of ICT and other e-learning tools stimulates the design of new flexible learning environment for interaction of students and educators offering possibilities for the productive educational process.

\section{Literature Review}

Online learning has been introduced into the system of Higher Education all over the world to make it open, user-friendly, and attractive for students and their learning needs. Moreover, according to UNESCO Guide for Policy Makers in Developing Countries, "online and blended education, in general, are seen by governments as a new and flexible way to educate at large scale whilst not increasing costs significantly (sometimes even increasing the quality of education whilst keeping total costs the same)" (Jansen \& Schuwer, 2016).

In Russian Federation the requirements of New Federal State Educational Standards of Higher Education 3++ and laws underline the importance of elearning implementation through all stages of Higher Education: Bachelor's Degree Programme, Master's Degree Programmes, Postgraduate Studies and Professional Training (Federal State Educational Standards of Higher Education, 2019). Thus, researchers and educators integrate digital technologies to assist in teaching and learning process and to design online learning environment at Russian universities. It also leads to the necessity of developing new skills and professional competencies for graduates. 
According to $21^{\text {st }}$ Century Skills Framework, the most important skills for students are Life and Career Skills, Learning and Innovation skills and Information, Media and Technology Skills (P21, 2019). Moreover, autonomy and digital literacy are mentioned in the requirements of Federal State Educational Standards of Higher Education 3++ and in the description of universal and general professional competences and outcomes that Bachelors of various majors acquire while studying at University (Federal State Educational Standards of Higher Education, 2019).

Besides, the online learning environment and innovative pedagogical approaches stimulate students' engagement and the personalization of the educational process. By integrating digital technologies and e-learning tools students may choose or design their personal learning trajectories according to their needs and requirements. They may manage their learning process and track academic performance.

One of the most popular learning formats in the system of Higher Education nowadays is blended learning. Blended learning is a key strategy of the $21^{\text {st }}$ century. UNESCO Guide states that by integrating online and face-to-face approaches, blended learning provides learners with both flexibility and support (Jansen \& Schuwer, 2016).

Basically, the term "blended learning" is associated with the application of ICT, e-learning tools, and distance learning educational technologies mixed with traditional forms of face-to-face communication (Caner, 2012; Dziuban et al., 2018; Graham, 2013; Picciano, 2009; Picciano, 2017). It is also often regarded as any method of delivery that combines the technology.

Hrastinski (2019) states in his study that blended learning means: "...essentially all types of education that include some aspect of face-to-face learning, and online learning is described as blended learning in the literature" (Hrastinski, 2019). At the same time some researchers consider blended learning as a new educational approach merging educator's practices with online learning (Voronin, Egorova, \& Khotuleva, 2019). Thus, there is still definitional ambiguity. The researchers underline, that blended learning is also used to describe other blends, such as combining different instructional methods, pedagogical approaches, and technologies, although these blends are not aligned with influential blended learning definitions (Hrastinski, 2019; Graham, 2013). There are a lot of studies analyzing the evolution of the term and various models of blending in modern educational process (Caner, 2012; Dziuban et al., 2018).

As a rule, students have the opportunity in blended learning to work in the classroom both in collaboration and individually. They are offered face-to-face contact with lecturers and other students; individual work is mostly organized autonomously using ICT and e-learning tools integrated into flexible forms of distant and online learning facilities. This format complies with the shift to networking activities and transforming centralized learning patterns.

In the given study we keep to the meaning of blended learning in High School as integrating e-learning tools and ICT into the traditional educational process and teaching approaches. 
Blended learning is relevant in the modern Higher Education System of Russia due to the changes in curriculum structure, syllabus, and load scheduling peculiarities of educational Institutions. Nowadays approximately more than half of students' working-time is autonomous work (Vystropova, 2016). Blended learning focuses on the importance of fostering students' critical thinking and autonomy through constant consolidation of basic knowledge and further skills development in online environment. ICT and other online learning facilities are assisting tools for increasing productivity and efficient solutions for various pedagogical tasks and teaching problems. ICT and other popular components of online learning constitute the structure of new learning environment in the system of Higher Education.

Furthermore, the popularity and quality of worldwide academic mobility as part of Higher Education and Professional Training is also closely connected with the development of modern digital educational environment. Russian universities design their own educational platforms of distant learning and online resources but use the products of other providers in blended learning models' design. For example, various online courses are integrated into the process of Academic and Professional Training at Russian Universities ${ }^{1}$. There are numerous collaborative partnerships' projects among universities to support, test, or improve educational process and quality of Professional Training. Students are offered to enroll in a course provided by any other educational institution or platform to get the credit. It consolidates their knowledge and helps to develop new vision and autonomy. This approach has been in high demand during the COVID-19 pandemic and lockdown in Russia.

It should be noticed, that the National Educational Platform of the Russian Federation "Open Education" ${ }^{2}$ is widely used in the system of Russian Higher Education. It comprises more than 685 officially certified online courses designed by famous professors of Russia for students of various training programs and majors. The project was developed by the Association of "National Platform of Open Education" established by leading Universities of Russia: Lomonosov Moscow State University, Peter the Great St. Petersburg Polytechnic University, Saint Petersburg University, NUST MISIS, Higher School of Economics, MIPT, Ural Federal University, ITMO University. The courses are free of charge and comply with the requirements of the Federal State Educational Standards of Russia with the possibility of official certification (National Platform of Open Education, 2020).

\footnotetext{
${ }^{1}$ e.g., Massive Open Online Courses (MOOC) on such platforms: www.universarium.org, www.lek torium.tv, www.openedu.ru, www.postnauka.ru, www.coursera.org, www.futurelearn.com, www. edx.org, www.stepik.org, www.khanacademy.org, www.udemy.com, www.udacity.com, etc.

${ }^{2}$ www.openedu.ru.
} 


\section{Problem Statement}

Modern teaching at Crimean universities can be characterized as a transitional period in the digitalization of Russian society (Garant Company Legal Information System, 2018). Nowadays e-learning tools and ICT provide a smooth educational process through all levels of Higher Education: Bachelor's/Master's Degree Programmes and courses of additional Professional Training.

Foreign language is a core discipline in Higher Education of Russia. With the transition to blended learning system in the $21^{\text {st }}$ Century Language class, we need to consider the peculiarities of new online interaction in modern educational process. Among significant methodological issues for professors are the adoption of new interaction patterns, techniques for developing learners' autonomy and collaboration skills, organizing assessment, and designing new teaching approaches in an online environment.

As it has been already mentioned, The Partnership for $21^{\text {st }}$ Century Skills was established by the National Education Association (NEA) in 2002 and the "Framework for $21^{\text {st }}$ Century Learning" was developed. Among 18 skills, as essential themes for learning in the $21^{\text {st }}$ century, "Four Cs" (i.e., Critical Thinking, Communication, Collaboration, Creativity) and Innovation were highlighted (Council of Europe, 2018). Teaching foreign languages at university is aimed at the development of these skills as well.

Besides, the CEFR introduces the concept of "Mediation". Mediation language activities, (re)processing an existing text, occupy an important place in the normal linguistic functioning of our societies. When the students use a language, several activities are involved; mediation combines reception, production, and interaction. They try not only to deliver a message but rather to develop an idea through what is often called "languaging" (talking the idea through and hence articulating the thoughts) or to facilitate understanding and communication (PowerSchool, 2016). We should point out, that mediation is connected with the development of new ways of communication and interaction in an online environment.

The aim of the research is to explore and analyze popular ICT and e-learning tools, applied for implementing a number of pedagogical tasks in blended learning, and to design flexible learning environment. The study also focuses on the ways of developing students' language and communication skills, autonomy and collaboration skills with the help of ICT and other e-learning tools in Higher Education. The research reveals peculiarities of blended learning issues integrated into the system of Higher Education (on the example of Bachelor's/Master's Degree Programmes and Professional Training at the Crimean universities). Moreover, concerning new teaching strategies design, the authors describe changes in approaches to teaching foreign languages and Academic English at university, because Languages and their aspects are essential components of Professional Training in online learning. 


\section{Materials and Methods}

The study is based on the results of an empirical study devoted to the analysis of ICT and e-learning tools used to organize educational process and to design flexible online learning environment at universities. It also comprises the results of conducted survey offered at Lomonosov Moscow State University Branch in Sevastopol, Sevastopol State University, V.I. Vernadsky Crimean Federal University, Institute of Foreign Languages (Simferopol) and S.I. Georgievsky Medical Academy.

The purpose of the survey was to find out the examples of e-learning tools and ICT used by students and professors to solve specific tasks in educational process. These results and participants' feedback are taken into consideration while designing a blended learning model and to test the format of new interaction patterns, developing innovative teaching strategies for online learning at universities respectively.

The study also involved interviewing students of Bachelor's and Master's Degree Programmes at Simferopol universities to identify their initial level of ICT awareness. ICT and e-learning tools were also widely applied in various programmes of additional Professional Training. The article presents the results of delivering two courses on professional development with the use of ICT: "Professional Training Modernization Strategy" at V.I. Vernadsky Crimean Federal University and "First Crimean Winter MOOC School" at Lomonosov Moscow State University Branch in Sevastopol. "First Crimean Winter MOOC School" for Russian Educators was offered by the Center of Online Learning Competencies "Lomonosov" in January-February, 2019. The participants from numerous Russian Universities and educational institutions were taught to use new educational technologies of distant learning and applied e-learning tools for team project management and collaboration in online environment.

\section{Results}

The design of a flexible online learning environment in Higher Education is challenging due to numerous factors. The process should take into account various theoretical and practical issues. This paper is mostly focused on the study of ICT and e-learning tools that are used in blended learning at Russian Universities.

In our opinion, the efficiency of training in the system of Higher Education can be achieved relying on the fusion of traditional teaching methods with new approaches through integrating ICT and e-learning tools on regular basis.

Online learning environment may include many components to organize remote educational process (e.g., Learning Management Systems (LMS), Learning Content Management Systems (LCMS), social networks and social media sites, online courses from leading MOOC platforms and providers, specific ICT and other e-learning tools).

Basically, online learning in Higher Education of Russia is implemented via Learning Management Systems (LMS) or Learning Content Management Systems 
(LCMS). Among popular solutions are Moodle, Blackboard, Teachbase, Mirapolis, Canvas, etc. For example, Sevastopol State University and Lomonosov Moscow State University Branch in Sevastopol have developed Moodle projects to manage the educational process in distant learning format: to deliver courses, share learning materials, communicate and track students' progress. The platforms ${ }^{3}$ comprise professors' learning/testing materials and courses that students may address to while preparing for classes individually. Moodle, and other LMS help to develop students' autonomy, self-discipline, time-management and other professional skills. LMS Moodle is also a bright example of an online learning tool used to organize learner-centered teaching in High School. But there are a lot of other additional ICT tools that may be used to increase students' productivity and allow professors to concentrate on giving feedback and mentoring with students.

Online learning is regarded nowadays as a new way of interaction in the educational process. Communication and sharing of information are organized with the help of ICT and popular e-learning tools. ICT, in terms of Computer Science, are digital technologies that allow you to create, save, distribute, transmit information, or provide services. In our research, under the term ICT we understand the set of methods, processes, software, and hardware, integrated to collect, process, store, distribute and present data or information by the participants through communication. ICT and e-learning tools are widely used in the online learning environment to communicate, get immediate feedback, track progress and academic performance, provide visualization of materials, share information, present data, for simulation, and to organize experiments and team projects. So, ICT and e-learning tools offer students and professors a wide range of flexible communication and interaction patterns, management and assessment opportunities in blended learning as shown in Table 1.

Table 1. The Use of ICT to Organize the Educational Process in Online Learning Environment

\begin{tabular}{|c|c|c|c|c|}
\hline \multicolumn{5}{|c|}{ Educational Process } \\
\hline Communication & $\begin{array}{l}\text { Information sharing } \\
\text { (search, processing, } \\
\text { storage, presentation) }\end{array}$ & $\begin{array}{c}\text { Interaction } \\
\text { patterns }\end{array}$ & Management & Assessment \\
\hline $\begin{array}{l}\text { Mobile phones, e- } \\
\text { mail, web } \\
\text { conferencing } \\
\text { services, } \\
\text { messengers, } \\
\text { social networks, } \\
\text { LMS, forums. }\end{array}$ & $\begin{array}{c}\text { Search engines, web } \\
\text { sites (including online } \\
\text { encyclopedias, } \\
\text { databases, dictionaries), } \\
\text { mass media and } \\
\text { educational resources; } \\
\text { various software and } \\
\text { applications for data } \\
\text { processing and } \\
\text { presentation, editing } \\
\text { tools; cloud storage } \\
\text { technologies. }\end{array}$ & $\begin{array}{c}\text { Tools for } \\
\text { individual and } \\
\text { team } \\
\text { collaboration, } \\
\text { group projects, } \\
\text { Realtime } \\
\text { visualization } \\
\text { tools (online } \\
\text { whiteboards). }\end{array}$ & $\begin{array}{c}\text { LMS, } \\
\text { educational } \\
\text { and project } \\
\text { management } \\
\text { platforms, task } \\
\text { and } \\
\text { organizing } \\
\text { apps, smart } \\
\text { daily planning } \\
\text { software. }\end{array}$ & $\begin{array}{c}\text { LMS, } \\
\text { online tests } \\
\text { and quiz- } \\
\text { making } \\
\text { services, } \\
\text { MOOCs, } \\
\text { etc. }\end{array}$ \\
\hline
\end{tabular}

\footnotetext{
${ }^{3}$ https://testmoodle.sevsu.ru/, https://distant.msu.ru/ and https://distant.sev.msu.ru/.
} 
The next important issues associated with the design of a productive online learning environment in Higher Education are educational content and new teaching strategies. Since 2005 the authors have taught on most programs and modules that the English Language Section has offered (Samoylenko, 2018). This also includes directing Masters' Courses at Sevastopol State University for several years, preparing students and educators for TKT exams and organizing continuing professional development activities. During Ph.D. studies at the University, we developed an interest in the interplay between ideas of language, identification practices, and contextualized intercultural communication aimed at the building of academic and digital literacy.

It is now generally accepted that English is used in teaching and learning in Higher Education throughout the world. The researchers consider English not only as of the core discipline in the curriculum but an efficient tool in the professional training of students in online learning environment.

According to Jenkins (2017), a Professor of Global English at the University of Southampton, language and intercultural communication skills are considered to be primary skills in our globalized world. Crystal (2006), a British linguist and academic, states that English is the language of the Internet and technologies as well. So, we may claim, that English is the language of intercultural communication in the online environment

Besides, Mauranen (2015) at the University of Helsinki studies English as a Lingua Franca in Academic Corpus (ELFA). English is also widely-spread in professional and academic online communication. That is why, it should be considered an important component of intensive professional training in Higher Education and online learning collaboration. Nowadays there are numerous scientific databases, digital libraries, and other resources for academics with their adopted rules and requirements (Scopus, Web of Science, Springer, Chicago, IEEE Xplore, etc.). Scientists analyze the manner and style of researchers' writing in English presenting their works online. Submitting papers written in English requires a clear vision, proper training, and experience.

The concept of English for Academic Purposes (EAP) has been the major trigger for the changes in English as a Foreign Language (EFL) program at Sevastopol State University. By the end of the Master's course, students must be able to read and analyze the contents of scientific publications, organize their own research, make presentations of research results, prepare articles, reports, summaries, reviews, and projects using the appropriate logical structure and ICT tools.

Therefore, we need to teach students of Bachelor's/Master's and Postgraduate programs the aspects of English academic discourse and communication issues through the use of ICT in online environment. The skills are developed nowadays using ICT and e-learning tools to build students' professional competences. In this context, the term "digital literacy" encompasses not only the skills of software and technologies implementation but mastering approaches and mechanisms of information processing and online communication in English and native language.

There is an abundance of ICT and e-learning tools that can be used in teaching and assessing the development of students' language skills online and offline: 
listening, reading, speaking, and writing. They may be integrated into the project of online learning environment design. From our experience, we suggest the following sources and tools shown in Table 2.

Table 2. ICT and E-Learning Tools Used by the Authors to Develop Language Skills in Blended Learning

\begin{tabular}{|c|c|c|c|}
\hline Listening & Reading & Speaking & Writing \\
\hline $\begin{array}{l}\text { Podcast hosting } \\
\text { sites: } \\
\text { Busssprout, } \\
\text { Captivate, } \\
\text { Simplecast, Podbean, } \\
\text { Transistor, BBC } \\
\text { podcasts, ELT } \\
\text { podcast. }\end{array}$ & $\begin{array}{c}\text { Mass media resources, } \\
\text { online newspapers and } \\
\text { journals: } \\
\text { AdForum, BBC, CNN, } \\
\text { Journalism.org. }\end{array}$ & $\begin{array}{l}\text { Web conferencing } \\
\text { services and } \\
\text { messengers: } \\
\text { Skype, Zoom, } \\
\text { Proficonf, } \\
\text { GoToMeeting, } \\
\text { Discord, ICQ, etc. }\end{array}$ & $\begin{array}{l}\text { Blogging } \\
\text { platforms; } \\
\text { Blogger, } \\
\text { WordPress, } \\
\text { Tumbir, } \\
\text { Squarespace, } \\
\text { Ghost, etc. }\end{array}$ \\
\hline $\begin{array}{l}\text { Video-sharing } \\
\text { platforms and } \\
\text { hosting services: } \\
\text { YouTube, Vimeo, } \\
\text { Tune, VBOX7. }\end{array}$ & $\begin{array}{c}\text { Online encyclopedias and } \\
\text { dictionaries: } \\
\text { Wiki, Encyclopedia } \\
\text { Britannica, Columbia, } \\
\text { Merriam-Webster } \\
\text { Dictionary. }\end{array}$ & $\begin{array}{l}\text { Learning software } \\
\text { and applications to } \\
\text { make recording: } \\
\text { Vocaroo, } \\
\text { VoiceThread, } \\
\text { MailVu, } \\
\text { Voxopop. }\end{array}$ & $\begin{array}{c}\text { Collaborative } \\
\text { online } \\
\text { whiteboards: } \\
\text { Miro, Linoit, } \\
\text { Stormboard, } \\
\text { AWW, Tricider, } \\
\text { Wallwisher, } \\
\text { Conceptboard, } \\
\text { Padlet, etc. }\end{array}$ \\
\hline $\begin{array}{l}\text { Educational } \\
\text { resources: } \\
\text { Ted-Ed, ESl Cyber } \\
\text { Listening Lab, } \\
\text { listenaminute.com, } \\
\text { elllo.org. }\end{array}$ & $\begin{array}{c}\text { Educational resources: } \\
\text { Breakingnewsenglish.com, } \\
\text { Tween Tribune, Dogo } \\
\text { News, National } \\
\text { Geographic, Science News } \\
\text { for Students, etc. }\end{array}$ & $\begin{array}{c}\text { Screencasts, slides } \\
\text { and videomaking and } \\
\text { editing software: } \\
\text { Bandicam, Windows } \\
\text { Movie Maker, } \\
\text { Camtasia Studio, etc. }\end{array}$ & $\begin{array}{c}\text { Social networks: } \\
\text { Twitter, } \\
\text { Instagram, } \\
\text { Facebook. }\end{array}$ \\
\hline
\end{tabular}

In order to identify initial ICT awareness of students of Bachelor's programme and to test their skills' level, the authors conducted a survey in the beginning of the study. The students of V.I. Vernadsky Crimean Federal University and S.I. Georgievsky Medical Academy took part in the research. The first question was: "Do you apply Information and Communication Technologies preparing your homework?" The affirmative answer was given by $77.5 \%$ of students, the negative answer was marked by $22.5 \%$ of respondents. The students were also asked to specify the ICT products they apply in learning process, their choices are displayed in Table 3.

Table 3. The Results of ICT Types' Survey Used by the Students at V.I. Vernadsky Crimean Federal State University and S.I. Georgievsky Medical Academy

\begin{tabular}{|l|c|}
\hline ICT Tools & The Number of Students (\%) \\
\hline $\begin{array}{l}\text { Electronic textbooks and manuals; digital } \\
\text { encyclopedias and reference books. }\end{array}$ & 67.5 \\
\hline Open education resources online. & 55 \\
\hline $\begin{array}{l}\text { DVDs and CDS with paintings/pictures, images } \\
\text { and other data. }\end{array}$ & 2.5 \\
\hline Video and audio facilities, etc. & 7.5 \\
\hline
\end{tabular}


Students, who gave negative answers, were also asked to give the reason why they ignored ICT in their training. The most common reasons were: a sufficient amount of information is still available offline or in printed sources; the lecturers mostly cover main issues of the topic during face-to-face meetings; for some students the book is more convenient to use Table 4 presents popular software used by student while learning foreign languages at university.

Table 4. The Examples of ICT Applied by the Students to Prepare for Language Classes at V.I. Vernadsky Crimean Federal State University and S.I. Georgievsky Medical Academy

\begin{tabular}{|l|c|c|}
\hline \multicolumn{2}{|c|}{ ICT Tool } & $\begin{array}{c}\text { The Number of Students } \\
(\%)\end{array}$ \\
\hline \multirow{4}{*}{$\begin{array}{l}\text { Popular Software to prepare } \\
\text { presentations, essays, } \\
\text { reports, projects and other } \\
\text { types of home assignments }\end{array}$} & Microsoft Word & 77.5 \\
\cline { 2 - 3 } & Microsoft Power Point & 50 \\
\cline { 2 - 3 } & Microsoft Excel & 22.5 \\
\cline { 2 - 3 } & Microsoft Office Publisher & 22.5 \\
\cline { 2 - 3 } & Microsoft Media Player & 10 \\
\cline { 2 - 3 } & CorelDraw & 5 \\
\cline { 2 - 3 } & Photoshop & 7.5 \\
\hline \multirow{3}{*}{$\begin{array}{l}\text { Online whiteboards for } \\
\text { individual and team projects }\end{array}$} & Visio & 2.5 \\
\cline { 2 - 3 } & other & 10 \\
\hline \multirow{3}{*}{$\begin{array}{l}\text { Audio recording software } \\
\text { programmes to prepare for } \\
\text { speaking or presentations }\end{array}$} & Tricider & 20 \\
\cline { 2 - 3 } & Wallwisher & 5 \\
\cline { 2 - 3 } & other & 5 \\
\cline { 2 - 3 } & Vocaroo & 22.5 \\
\cline { 2 - 3 } & VoiceThread & 17.5 \\
\hline
\end{tabular}

Moreover, ICT and e-learning tools can be applied to develop students' autonomy and skills of teamwork and collaboration including time-management, task priorities, planning, self-discipline, and flexibility (e.g., various collaborative presentation and documents editing tools, smart daily planning, task and organizing apps, mind mapping services and applications, cloud storage, CRM or Customer Relationship Management and other project management platforms, etc.). These examples of ICT may be incorporated or used as additional components in the design of an online learning environment.

The research under review comprises the results of ICT types used in the teaching and assessment of both undergraduate students and participants of further Professional Training programs (Samoylenko, 2018). Let's analyze the cases of additional professional training programs with ICT and e-learning tools organized in 2019. The participants enrolled in the professional development program "Professional Training Modernization Strategy" were taught to apply ICT and other e-learning tools as part of integrating creative approaches to problem-solving tasks in the educational process. After mastering the course, the trainees had to design their own individual programs of additional professional training based on the skills and knowledge obtained. The course participants were offered to prepare for meetings autonomously or being engaged in teamwork. The assignments 
included such activities as collecting data and information processing, preparing reports, case-study assignments, brainstorming procedures, making portfolio using various ICT. The task formats were aimed at the development of professional and digital skills needed for collaborative learning and team project management.

Another example of an additional professional training program realized partially in the online learning environment is the "First Crimean Winter MOOC School" for Russian Educators. It was organized at Lomonosov Moscow State University Branch in Sevastopol in January-February, 2019. Over 100 participants from numerous Russian Universities and educational institutions were taught to apply digital learning technologies in developing and presenting team projects. The aim of the programmes was to teach users to integrate ICT and new approaches in their day-to-day work, curriculum design and framework for blended learning at universities. The projects covered various methodology issues (e.g., blended learning models overview; the specifics of new curriculum and syllabus formats; the peculiarities of creating, delivering, and promoting online courses; university branding strategies, etc.).

The training program was designed as a blended learning model itself, including MOOC elements (theory part), face-to-face meetings, project management, and teamwork sessions (practical assignment). The course was offered by the Center of Online Learning Competencies "Lomonosov". The learning materials were placed at https://lms.profedu.online/ and delivered in a MOOC format. The enrolled users studied lectures, discussed questions, and issues through course forum and chat room. Much attention was paid to problem-solving activities. While creating and presenting team projects the participants applied various online tools and ICT for team collaboration to discuss ideas, prepare, deliver, and present materials of the projects that are bright examples of organizing teamwork at distance. The projects were presented online, so all registered users could follow the procedure and give their immediate feedback. This interaction pattern proved its feasibility and efficiency. The course contained stages of peerto-peer evaluation as well. The program was designed to develop vital professional competences and digital literacy. Moreover, the proposed format supports the priority of the "Four Cs" development (i.e., Communication, Critical Thinking, Creativity and Collaboration) through all stages of Higher Education and further Professional Training.

Table 5 presents the examples of ICT and team collaboration tools used by the participants of professional development programs reviewed.

Table 5. ICT and E-Learning Tools Used for Team Project Collaboration in Additional Professional Training Programmes

\begin{tabular}{|c|c|}
\hline \multicolumn{2}{|c|}{ Team Project Management in Education } \\
\hline Information processing & Communication \\
\hline $\begin{array}{l}\text { Information search and data collection: } \\
\text { WWW, scientific databases and online } \\
\text { libraries, mass media resources }\end{array}$ & \multirow{2}{*}{$\begin{array}{c}\text { Synchronous: group messengers (WhatsApp, } \\
\text { Viber, Telegram, Skype), web conferencing } \\
\text { services (Zoom, BigBlueButton, etc.), chats, } \\
\text { forums. }\end{array}$} \\
\hline Sorting data: Microsoft Office, etc. & \\
\hline $\begin{array}{l}\text { Data analysis: } \\
\text { Microsoft Office and other software packages } \\
\text { (Excel, Visio). }\end{array}$ & $\begin{array}{l}\text { Asynchronous: e-mail services, social networks } \\
\text { (Facebook, Twitter, Instagram), file-sharing } \\
\text { technologies (OneDrive, Dropbox, Google }\end{array}$ \\
\hline
\end{tabular}


Presentation of the results and materials: Microsoft Office (Word, Visio, Power Point), Adobe Photoshop, CorelDraw, Mind Mapping services, movie making and editing

programmes.
Drive, etc.), collaborative document editing tools (Google Forms), document management systems.

Taking into account the results of the study, the following conclusions can be made: the level of modern students' ICT skills can be assessed as a "confident user". The application of ICT is widely-spread through all levels of professional training in Higher Education: Bachelor's/Master's programmes and additional professional development courses that is supported by state policy of Russia. The universities of the Russian Federation take efforts to design their online learning environment, taking into account learners' needs, the requirements of Federal State Educational Standards of Higher Education, and the worldwide experience of blended learning. Sevastopol and Crimean Universities adopt Moodle projects combined with various additional ICT, e-learning tools, MOOCs and other resources to design flexible online learning environment that would meet the needs of professors and students.

ICT and other digital educational tools and services are applied to organize and manage the educational process in blended learning (i.e., to maintain communication and interaction, to share information, to track progress, and organize assessment and peer-to-peer review). These tools are also applied to develop the Language skills of students while learning foreign languages in blended learning model. ICT and e-learning facilities are used by professors to evaluate listening, reading, speaking, and writing skills at the university. Moreover, they are efficient tools for project management, teamwork, and collaborative learning.

At the same time, the professors are currently being faced with methodological limitations and a shortage of support in online learning. The results of the research may be used to design new teaching approaches and methodological recommendations to organize efficient interaction in online learning. The outcomes of the study can be also applied for designing syllabus and various online courses for undergraduates (e.g. MOOC "Foreign Language for Academic and Scientific Purposes") or additional online Professional Training programmes.

\section{Conclusion}

The research has been aimed at the analysis of ICT and e-learning tools applied by the students and professors at Crimean Universities in blended learning (i.e., face-to-face meetings mixed with online instruction and ICT use for educational needs). The results are taken into consideration to develop innovative teaching strategies and approaches to support the educational process online in the system of Higher Education and massive transition to blended learning in Russia due to Covid-19.

Designing a flexible and reliable online learning environment is quite challenging. It requires both technical skills (digital literacy fundamentals) and 
methodological assistance. First of all, to organize educational process online students and professors must have equipment or devices (personal computers, a tablet, a smartphone, or any other type of mobile gadget) with a broadband internet connection.

Secondly, you have to know the basics of digital literacy and develop your skills in ICT needed to make or deliver courses through LMS or popular MOOC platforms. To organize successful online interaction there must be developed university platforms with approved free access to online learning materials and tools (e.g., Moodle or other channels of online communication, such as communities in social networks or groups in messengers). At the same time, we must follow laws and regulations on the use of materials from the WWW and protect the rights of intellectual property.

Moreover, the design of new teaching strategies in online learning environment is of primary concern. The proper balance between online and faceto-face components in blended learning at the university is required. Ways of students' engagement and their motivation are also important. Online learning is also based on students' autonomy and individual work. That is why, the professors must provide precise but at the same time extensive instructions for learning and assessment procedures. Clear delivery of cognitive tasks, detailed algorithm, and instructions are necessary for students' awareness of the educational process in blended learning. The professors must present the course structure overview, discuss assessment forms, types of tests and criteria, set deadlines in advance to eliminate difficulties and to achieve success in online learning. Methodological support and consultation by professors are key issues in blended learning implementation at universities. ICT and other e-learning tools maintain communication and interaction patterns, support interactive learning where immediate feedback matters. ICT tools are focused on principles of practiceoriented learning in Higher Education. Digital learning technologies can be used effectively as additional tools to consolidate or test students' knowledge and develop crucial skills within new online learning environment.

\section{References}

Council of Europe (2018). CEFR companion volume with new descriptors. Council of Europe.

Caner, M. (2012). The definition of blended learning in higher education. In P. Anastasiades (ed.), Blended Learning Environments for Adults: Evaluations and Frameworks. Hershey, PA: IGI Global.

Crystal, D. (2006). Language and the internet. Cambridge University Press.

Dziuban, C., Graham, C.R., Moskal, P.D., Norberg, A., \& Sicilia, N. (2018). Blended learning: the new normal and emerging technologies. International Journal of Educational Technology in Higher Education, 15(3): 1-16.

Federal State Educational Standards of Higher Education (2019). Federal state educational standards of higher education (bachelor's degree programme) 3++. Retrieved from: http://fgosvo.ru/fgosvo/142/141/16. [Accessed 29 December 2020].

Garant Company Legal Information System (2018). Passport of the national programme "Digital Economy of the Russian Federation". Approved by the Presidium of the Presidential Council for Strategic Development and National Projects on December 
24, 2018. No. 16. Retrieved from: https://base.garant.ru/72190282/. [Accessed 20 October 2020] (In Russian).

Garant Company Legal Information System (2008). Strategy of development of information society in the Russian Federation of February 7, 2008. No. PR-212. Retrieved from: https://www.garant.ru/products/ipo/prime/doc/92762/. [Accessed 25 October 2020]. (In Russian).

Graham, C.R. (2013). Emerging practice and research in blended learning. In M.G. Moore (ed.), Handbook of Distance Education ( $3^{\text {rd }}$ Edition, 333-350). New York, NY: Routledge.

Hrastinski, S. (2019). What do we mean by blended learning? TechTrends, 63(Feb), 564569.

Jansen, D., \& Schuwer, R. (2016). Making sense of MOOCs - A guide for policy makers in developing countries. France: UNESCO and Commonwealth of Learning.

Jenkins, J. (2017). Mobility and English language policies and practices in higher education. In S. Canagarajah (ed.), The Routledge Handbook of Migration and Language. London: Routledge.

Mauranen, A. (2015). English as a global Lingua Franca: changing language in changing global academia. In K. Murata (ed.), Exploring ELF in Japanese Academic and Business Contexts (pp. 29-46). Amsterdam: John Benjamins.

National Platform of Open Education (2020). Online educational platform and MOOC provider of Russia. Retrieved from: http://npoed.ru/about. [Accessed 25 December 2020].

Nikonov, E., \& Shamis, E. (2016). Generations theory basics. Moscow: Synergy.

Partnership for $21^{\text {st }}$ Century Learning - P21 (2019). Framework for $21^{\text {st }}$ century learning. Washington, DC: P21.

PowerSchool (2016). Connecting the $4 \mathrm{Cs}$ of $21^{\text {st }}$ century education (with a $5^{\text {th }} \mathrm{C}$ !). Retrieved from: https://www.powerschool.com/resources/blog/connecting-4-cs-21stcentury-education-5th-c/. [Accessed 25 November 2020].

Picciano, A.G. (2009). Blending with purpose: the multimodal model. Journal of Asynchronous Learning Networks, 13(1), 7-18.

Picciano, A.G. (2017). Theories and frameworks for online education: seeking an integrated model. Online Learning, 21(3), 166-190.

Samoylenko, N. (2018). Language portfolio: students' autonomous learning and language learning achievements. Scientific Letters of Academic Society of Michal Baludansky. Slovakia, 3(6): 124-130.

Voronin, D., Egorova, G., \& Khotuleva, O. (2019). Experience in the implementation of blended learning with elements of project activities in the pedagogical Master's program with the example of training teachers of biology. Perspectives of Science and Education, 38(2), 155-166.

Vystropova, O. (2016). Organization of the students' self-regulating work in a foreign language in the form of the PowerPoint presentation at the medical university. Azimuth of Scientific Research: Pedagogy and Psychology, 1(14), 27-29. 